\title{
The Effects of Public Opinion on Multi-Track Diplomacy Actors' Critical Assessment of Kenya's Presidential Elections
}

\author{
David Owuor Okoth Sanmac, Pontian Godfrey Okoth, Standslause Elijah Onyango Odhiambo \\ Department of Peace and Conflict Studies, Masinde Muliro University of Science and Technology, Kakamega, Kenya \\ Email: sanmac2005@yahoo.com
}

How to cite this paper: Sanmac, D. O. O., Okoth, P. G., \& Odhiambo, S. E. O. (2021). The Effects of Public Opinion on Multi-Track Diplomacy Actors' Critical Assessment of Kenya's Presidential Elections. Open Journal of Political Science, 11, 655-681.

https://doi.org/10.4236/ojps.2021.114042

Received: June 24, 2021

Accepted: October 19, 2021

Published: October 22, 2021

Copyright $\odot 2021$ by author(s) and Scientific Research Publishing Inc. This work is licensed under the Creative Commons Attribution International License (CC BY 4.0).

http://creativecommons.org/licenses/by/4.0/

\begin{abstract}
This paper discusses the effects of public opinion on multi-track diplomacy election monitors' critical assessment of Kenya's presidential elections with reference to such elections held from the year 2007 to the year 2017. The study was conducted in Nairobi between July and October 2020 using questionnaires among voters, focus groups discussions and key informant interviews among state and non-state actors in the political system. It was found that it was believed by the majority of respondents that multi-track diplomacy actors that monitored Kenya's presidential elections were influenced by public opinion thereby affecting their critical assessment of the outcomes of the elections, putting the credibility of their statements, reports and verdicts insofar as their role in promoting credible elections by preventing, detecting and deterring election fraud, to question.
\end{abstract}

\section{Keywords}

Assessment, Campaign, Credibility, Critical, Diplomacy, Effects, Elections, Horserace, Media, Monitoring, Multi-Track, Opinion, Polls, Political, Presidential, Public

\section{Introduction}

When employed, election observation is one of the strategies hoped to identify electoral irregularities and yield efforts to contain election fraud (Kelley, 2010; Tapoko, 2017: p. 46). This could prevent manipulation of the vote count that would lead to wrong totals to be announced and certified as credible results (Tapoko, 2017: p. 46; Gibson \& Zimmerman, 2015). Election observation is carried out by foreign (international) and domestic (citizen) observer missions and 
groups largely constituting Multi-track diplomacy. This practice has become global and a norm has existed since 1948, the first being the UN-led election observers to South Korea for its Constituent Assemblies' elections (Tapoko, 2017: p. 46).

Election observers (ranging from government officials, professionals/experts, businessmen (and/or multinational corporations), the media and public opinion shapers, private citizens, epistemic community, activists, religious institutions, and the donor community) essentially are the very actors that fall under multi-track diplomacy (MTD) (Natolooka, 2017; Mapendere, 2000: p. 71; McDonald, 2003). They are expected to critically assess the electoral process on the basis of national legislation and international standards according to the United Nations Declaration of the Principles of International Election Observation and Code of Conduct for International Election Observers (United Nations, 2005) and the Code of Conduct for Non-partisan Citizen Election Observers and Monitors (GNDEM, 2018).

These entities are expected to demonstrate international interest, strengthen public confidence in the electoral process, and expose potential irregularities (Ndulo \& Hong, 2017: p. 1). However, there are general conclusive questions asked that cast doubt on the credibility and effectiveness of election observation especially in Africa (Kelley, 2010: p. 5; Lynge-Mangueira, 2012). Public opinion especially the judgement of the public of the election is considered an important factor in election observation (Shah, 2015) but this was not based on any empirical research thus remains untested.

To that extent, it was plausible that the observation of Kenya's presidential elections in 2007, 2013 and 2017 was affected by public opinion but no study had been done to ascertain the assumption. By and large reports of multi-track diplomacy actors that monitored Kenya's August 2017 presidential election were not concomitant with the Supreme Court nullification of the election putting questions on whether the MTD actors were influenced by public opinion among other factors.

Public opinion denotes "the collective beliefs, judgments or views held by the majority of citizens of a country about public policy or actions of government"; where it refers to "what members of the public think or feel about government proposed policy or action already taken by government"; and depends on country or region given the issue at stake; may be dependent of the level of education; but may also not be the opinion of the majority, rather of those who can influence the government as a collective voice (Udeuhele, 2011).

However, a detailed analysis of the sources clearly revealed that the literature had not discovered that election monitoring could also be influenced by local perception and local and international political figures; while the local perception may be influenced by powerful international and local politicians in their favour, and as well, by or in conspiracy with external actors individually or collectively secretly (Moore, 2018). This paper examines the effects of public opi- 
nion on MTD actors' critical assessment of Kenya's presidential election outcomes and the resulting effects on their role in preventing, detecting and deterring election fraud yielding credibility of election observation.

Therefore, the objective of the study was to examine the effects of public opinion on the multitrack diplomacy actors in monitoring Kenya's presidential elections. In the next section, the methodology used is discussed.

The question this study sought to address was: what effects did public opinion have MTD actors in monitoring Kenya's presidential election?

There were three justifications for the study: academic, policy, and philosophical justifications. From an academic point of view, research on election observation as a diplomatic activity was scanty if not absent. This study sought to bridge that gap. In addition, and of major importance, no study had investigated nor recognized election observation as a multi-track diplomacy process, which this study did. More significantly, it sought to investigate election observation as MTD process and assess it as a tool for monitoring the credibility and integrity of Kenya's presidential elections. For this reason, when more focused and thorough studies are done, more literature is availed for academicians to make a balanced and policy-oriented judgment, in this case, on the competence of MTD as an instrument of monitoring elections. The study would enhance contextualization of the salient concepts in the discourse among them Multi-track diplomacy, electoral integrity, credibility, fraud, foreign electoral intervention. Finally, IR does not have a particular methodology that can apply in all researches (Lamont, 2015: pp. 15-17; Williams, 2004). This study was to make a contribution towards resolving this debate.

From a policy perspective, the study was justified on grounds that researches in International Relations (IR) have grounds on some 'event' in international or global politics with an aspiration to generate relevant policy (Lamont, 2015: p. 14). Most research essays in IR are empirically grounded in some event in international politics and aspire to be policy-relevant. In fact, the study employing an empiricist approach to acquiesce to positivism sought to be as Lamont (2015) avers, of policy-relevance and inform some action by decision-makers.

Owiso (2017) observes, "Elections in Kenya appear to be periods when people pour out grudges and settle scores against neighbours through violence" with the executive subduing the EMBs; as Wanyande (1987) posits, that therefore they control to subdue peoples' rights and freedoms" (Wanyande, 1987). Cox and Weingast (2017) contend this nurtures and precipitates violence as a way of expressing discontent. Laugesen (2017) noted a growing mistrust by Kenyans in democracy. From experience, the researcher noted that since December 2007, after every announcement of the presidential election result by the chairman of the EMB, the outcome was disputed. This strongly sparked heightened debate at the national level which had in effect translated into violence between the supporters and ethnic groups associating with them, of one losing candidate(s) against the supporters and ethnic groups associating with the winner, in the ex- 
perience of the researcher. Yet, these elections had been observed far and wide and observers provided their reports which should inform direct and specific policies on addressing the gaps.

Election observers do not operate in a perfect environment, their freedom is constrained by immense pressure from the public, the government and the opposition to endorsing their claims vis-a-vis the polls (Elklit \& Reynolds, 2010). They are condemned by either of the political divides testing their impartiality based on in whose favour coincidentally they report, putting their credibility to question unnecessarily (Nginya, 2018). No study has recommended policy solutions to this. Kenya's foreign policy had not addressed such either. The recommendations of the study would surely contribute towards development of Kenya's foreign policy and on the basis of domestic policy, address the gap. This study would inform the Government of Kenya, African Union, the United Nations, the international non-governmental organizations and intergovernmental organizations that send election observers abroad on their level of contribution to credible election outcomes. it would gauge the perception of the public on the credibility of presidential election outcomes and the expose interplay between the public perception and the position of MTD election monitors and their true 'mission' in the elections. It would also review the relevance of foreign election observers to the Kenyan election outcomes so that appropriate policy and legal frameworks may be developed and adopted for posterity. The study recommendations are expected to yield proposals for feasible national policies that will guide elections and election observation.

From philosophical point of view, the study was conducted since International Relations (IR) has its origin as a subset of other disciplines, namely, history, international law, economics and political theory (Brown, 2013; Lamont, 2015: p. 1). Actors and issues in IR that claim to be shaping the philosophy in IR or issues in international relations which philosophy seeks to examine, interpret and understand, are multifaceted each with a claim to be shaping politics among nations or contributing to global governance. Such are the States, INGOs, and MNCs (Lamont, 2015: p. 26), warranting Lamont (2015) to recommend research to provide a means to test many of these claims. Apparently, these are the very actors that also do send election observation mission. On the one hand, a number of scholars retort that election observation is a prominent tool for promoting election integrity and democracy and can also promote public confidence in an election (Kelley, 2009; Nginya, 2018). On the other, scholars contend that it can portray biases legitimizing governments born out of questionable elections (Kelley, 2010: pp. 5-7), endorse a flawed election (Gibson \& Zimmerman, 2015), and may greatly differ from public assessments (Norris et al., 2013). Shah (2015) contended that it is the local opinion which actually matters and which legitimizes elected governments, not a critical assessment by observers, especially international assessment. This philosophical confusion provided the philosophical justification to investigate claims. 
The study sought to investigate the effectiveness of multi-track diplomacy as an instrument of monitoring Kenya's presidential election outcomes, 2007-2017 to produce new knowledge epistemologically. The first is empiricism (positivism: knowledge gained through experience and observations) (Linklater, 1996; Whetten, 1989). This is the side familiar IR theories including the ones applied in the study such as liberal internationalism or its neo-version, power theory, and social choice theory fall.

The second is interpretivism (reflectivism or post-positivism) which seeks to understand social meanings embedded in international or global politics by questioning the social and power structures characteristic of politics among nations (Lamont, 2015: p. 19; Braemoeller \& Satori, 2002: p. 144). This is despite the 'a fundamental division within the discipline' (Burchill et al., 2013; Burchill \& Linklater, 2009), with an attempt to resolve the confusion arising from, but while, entrenching appreciation of IR's plurality in methodologies, its diversity in research methods (Lamont, 2015), and the principle of incommensurability (Feyerabend, 1975) and the existence of the numerous methods and methodological traditions (Lamont, 2015).

This was methodologically rigorous research that met the standards of inquiry as recommended in Lamont (2015) was desired. The researcher also recognized that in IR study, replicating methodology would not necessarily yield conclusions (Braemoeller \& Satori, 2002). The existing researches on and around the problem of the study exhibited a dearth of IR-specific philosophical justification of this kind.

\section{Methodology}

The study from which this paper emanates was epistemological and was conducted both from primary data and secondary data approaches. Primary data was collected from voters and relevant government and non-governmental institutions in Nairobi. The questionnaire was administered among 384 individual voters in 8 out of the 17 constituencies comprising Nairobi City County, where Kenya's seat of power rests. Focus group discussions were held with 32 participants half of which were drawn from two natural groups and the half from 2 expert groups suspected to have information on election observation and elections in general with specific focus on the presidential elections held in 2007, 2013 and 2017. As well 25 key informant interviews were conducted with the interviewees drawn from the election management body-the Independent Electoral and Boundaries Commission, Ministry of Foreign Affairs, Kenya National Commission on Human Rights, posters, religious leaders including Muslim and Christian, Parliament of Kenya, local and international observers, academics, the civil society among others. The total sample size of the population of more than 4 million residents of Nairobi City County of which over 2 million were registers at the time, reached was 441 . Secondary data was collected taking care of the reliability, sufficiency, and accuracy of the data with the dependent variable 
(Critical assessment of Kenya's presidential election outcomes) and the independent variable (effectiveness of multitrack diplomacy actors (election observer missions-EOMs) in mind. Quantifiable data were analysed using descriptive statistics by aid of statistical packages for social sciences (SPSS) while qualitative data were analysed using content analysis. Findings were presented in form of tables, figures, plates, and narratives. In the next section, findings are presented and discussed.

\section{Effects of Opinion Polls and Media Influence on Multi-Track Diplomacy Election Monitors' Critical Assessment of Elections}

In the relationship between the voters and the presidential candidates as may be and maybe with candidates for other politically electable candidates, the role played by polls hinges upon their dissemination by the mass media (Moy \& Eike, 2012).

But public opinion itself has no boundaries. Nwogbaga (2016) argues that public opinion may be divergent while Norris et al. (2013) observes that international assessments of an election may greatly differ from public assessments.

Bush \& Prather (2018) contended that the identity of international election observer missions may affect the local perception towards enhanced electoral credibility. Going beyond Bush \& Prather (2018), in the case of Kenya's presidential elections from 2007 to 2017, election observer missions both foreign and domestic were influenced by opinion polls and political campaign media reports according to the findings summarized and presented in Table 1.

From Table 1, majority 269 (69.5\%) of the respondents said that the international election observer missions to Kenya's 2017 presidential elections between 2007 and 2017 were influenced by opinion polls and political campaign media reports while 117 (30.5\%) of the respondents disagreed.

It was evident that $132(69.8 \%)$ of the female and $135(69.6 \%)$ male respondents agreed to this while $30.2 \%$ and $30.4 \%$ of the female and male respondents respectively disagreed. 45 (93.8\%) of the respondents from Mathare constituency agreed to this question. From the findings, 10 (76.9\%) of the respondents who

Table 1. Opinion polls and political campaign media reports influence on credibility of MTD EOMs' critical assessment of Kenya's presidential elections.

\begin{tabular}{|c|c|c|c|c|c|c|c|}
\hline & & \multicolumn{6}{|c|}{$\begin{array}{l}\text { Do believe opinion polls and political campaign media reports } \\
\text { influence on MTD EOMs affected the credibility of their monitoring of } \\
\text { Kenya's presidential elections? }\end{array}$} \\
\hline & & \multicolumn{2}{|c|}{ Yes } & \multicolumn{2}{|c|}{ No } & \multicolumn{2}{|c|}{ Total } \\
\hline & Male & 135 & $69.6 \%$ & 59 & $30.4 \%$ & 194 & $100.0 \%$ \\
\hline \multirow[t]{2}{*}{ Gender } & Female & 132 & $69.8 \%$ & 57 & $30.2 \%$ & 189 & $100.0 \%$ \\
\hline & Total & 267 & $69.5 \%$ & 117 & $30.5 \%$ & 384 & $100.0 \%$ \\
\hline
\end{tabular}


had voted once were in agreement with this question while $41(36.3 \%)$ of the respondents who had voted thrice did not agree.

Opinion polls were thought to have been useful in providing valuable information about elections contestant and could have helped voters cast their votes based on popularity of the candidates. However public perception may lead to protests and demonstrations should the outcome be not concomitant with the opinion erstwhile held to be true. This may cause political instability (Nkwede \& Itumo, 2016; p. 3).

Based on the study conducted on the effects of public opinion on multi-track diplomacy election observer missions' critical assessment of Kenya's presidential election outcomes, it was observed that opinion polls were significantly relied on by the media and the domestic observers. It was used to gauge the performance of the candidates and their popularity assumed from public perception and as influenced by or influence on the media images of the same, with respect to the Kenyan elections of December 2007.

A number of opinion polls institutes and organizations including the Steadman and Ipsos Synovate then, published results on the presidential candidates. To the extent of employing poll agencies, the media influenced the pollsters for example; Nation Media Television famous as NTV employed the Kenyan Steadman market information company to conduct regular polls, which thus received the widest attention, influence on the views of every actor and stakeholder in Kenya's electoral system from the Government itself, political parties both in government and in the opposition, political candidates, the security and intelligence apparatus, and above all, the EMB, national or domestic or local observers, and the voters. It is noted that these were the entities the election monitors especially foreign, relied on and are in most cases their first contact, to brief them.

From a review of reports by most election observer mission, IRI's report on the December 2002 election revealed that some of the observers contributed towards opinion polls, and IRI was among the leading observer missions with such a practice. While explaining its presence and activities in Kenya, IRI admittedly wrote, "After a hiatus in programming, IRI launched a public opinion polling program (in Kenya) in June 2000 which it continued with during the 2007 elections, which received significant media attention and covered a myriad of topics such as constitutional reform, governance and election issues" (IRI, 2008: p. 39).

Confirming reliance on opinion polls and designed public opinion, on the August 2017 presidential election and the electoral environment, The Commonwealth Secretariat wrote:

A study for GeoPoll during this period found that trust levels amongst Kenyans for social media as a source of election news was lower than that for mainstream media. However, despite this, a significant proportion of Kenyans cited social media as their main source of election news. (Commonwealth Secretariat, 2018: p. 3)

Therefore, while Kenyans had low levels of trust in social media and more 
trust in mainstream media, easily accessed was social media for election news. The implication was that the information in the election news available in social media was largely inaccurate but then again it spread wider than what could have been more accurate information. The "unfortunate" bit wads that the election monitors were influenced by media information including that from social media.

\section{Local Political Power Influence on Multi-Track Diplomacy Election Monitors' Processes and Reports}

Locally, those who control the state in one way or the other may vex their muscles during elections in an attempt to influence the processes and outcomes of election monitoring entities. This can be done directly or indirectly. As observed, the invitation and finally accepting MTD EOMs as monitors is subject to the Government of Kenya through the Ministry of Foreign Affairs and the EMB. The security of the EMBs is in the hands of the state and as well, the information they are supposed to access and not to as emerged in the previous chapter. To this extent, the researcher investigated perspectives on whether local power affected the MTD EOMs.

\subsection{The Influence of Opinion of Dominant Party on Election Monitors}

Opinion polls were useful in providing valuable information about election contestant and helped voters cast their votes based on popularity of the candidates but influence on public perception may lead to protests and demonstrations should the outcome be not concomitant with the opinion erstwhile held to be true such as the belief by and of a party's supporters that their candidate or party would win then it turns out otherwise. This may cause political instability (Nkwede \& Itumo, 2016: p. 3).

The study conducted in Kenya found that majority of voters and players in the country's electoral system believed election monitors in their critical assessment of Kenya's presidential elections relied on information from public opinion largely designed by dominant political parties. Table 2 shows detailed analysis.

Findings from Table 2 shows that majority 284 (74\%) of the respondents said that foreign observers largely based their observation the information from public opinion designed by the dominant political parties while 100 (26\%) of the respondents had a contrary opinion about the same. It was observed that 141 (74.6\%) of the female and $143(73.7 \%)$ male respondents agreed to this while 48 (25.4\%) and $51(26.3 \%)$ of the female and male respondents respectively disagreed. From Table, $80.9 \%$ of the respondents who had voted more than five times were in agreement with the statement, believing election monitors based their observation on information from public opinion designed by the dominant political parties.

Public opinion may be impaired by ethnic and political heterogeneity that results in divergent public perception and political manipulations that impair 
Table 2. The influence of public opinion designed by dominant political party on election monitors' processes and reports.

\begin{tabular}{|c|c|c|c|c|c|c|c|}
\hline & \multirow[b]{3}{*}{ Male } & \multicolumn{6}{|c|}{$\begin{array}{l}\text { Do you believe election monitors based their observation on } \\
\text { information from public opinion designed by the dominant } \\
\text { political parties? }\end{array}$} \\
\hline & & \multicolumn{2}{|c|}{ Yes } & \multicolumn{2}{|c|}{ No } & \multicolumn{2}{|c|}{ Total } \\
\hline \multirow{3}{*}{ Gender } & & 143 & $73.7 \%$ & 51 & $26.3 \%$ & 194 & $100.0 \%$ \\
\hline & Female & 141 & $74.6 \%$ & 48 & $25.4 \%$ & 189 & $100.0 \%$ \\
\hline & Total & 284 & $74.0 \%$ & 100 & $26.0 \%$ & 384 & $100.0 \%$ \\
\hline \multirow{6}{*}{$\begin{array}{l}\text { Number of } \\
\text { Times Voted for } \\
\text { President of } \\
\text { Kenya }\end{array}$} & Once & 9 & $69.2 \%$ & 4 & $30.8 \%$ & 13 & $100.0 \%$ \\
\hline & Twice & 70 & $76.9 \%$ & 21 & $23.1 \%$ & 91 & $100.0 \%$ \\
\hline & Thrice & 82 & $72.6 \%$ & 31 & $27.4 \%$ & 113 & $100.0 \%$ \\
\hline & four times & 68 & $68.7 \%$ & 31 & $31.3 \%$ & 99 & $100.0 \%$ \\
\hline & $5-7$ times & 55 & $80.9 \%$ & 13 & $19.1 \%$ & 68 & $100.0 \%$ \\
\hline & Total & 284 & $74.0 \%$ & 100 & $26.0 \%$ & 384 & $100.0 \%$ \\
\hline
\end{tabular}

reality (Saltman, 2006: p. 4). It is observed that the history of election frauds is imbedded in the perception of the public (Saltman, 2006: p. 2). Empirically, the study conducted on the effects of public opinion on election monitors' critical assessment of Kenya's presidential election outcomes found out that all election observers were briefed.

It was observed from reports of certain election observer missions that it was a tradition that on their arrival to observe elections in Kenya, the observers relied on political parties in which case the dominant ones for briefing to understand the political situation. This was even indicated in the reports of The Commonwealth Secretariat from 2002, the IRI from 1992, the European Union Election Observer Mission Kenya 2017 (2008), and the Carter Center (various). In these briefings, the observers might have been persuaded to take a certain direction in its observation. The IRI wrote,

IRI delegates and staff involved in the observer mission held meetings with experts on Kenyan politics, representatives of Kenyan political parties and leaders from civil society and international organizations that operate in Kenya to gain a better understanding of the political environment leading up to the elections... Delegates and staff were first briefed on the overall political situation. Kenya Domestic Observer Forum (KEDOF) briefed IRI's delegation on its domestic observation efforts, how it viewed the campaign period and specific things for which election observers should be on the lookout (IRI, 2008).

From this submission by IRI and as it reflected across reports of most of the foreign EOMs, the MTD EOMs lost touch with the standard monitoring tool and guidelines and DOP and resorted to convenient techniques. While forging long-term relationships between foreign and local MTD actors on election ob- 
servation, the relationship should be objective. However, the Kenya Domestic Observer Forum (KEDOF) was seen to be guiding and the foreign observers such as the IRI were seen to be accepting and adopting the perspective that observation was to be skewed. The local entity was conditioning observation by the foreign entities, and IRI did not give its own position regarding whether it chose a different path. Having long-term relationship did not mean foreign observers should not have sent its long-term observers to do independent observation.

The views of key informant interview respondents were sought regarding this thematic issue of study. In reaction, one of the respondents charged that:

...The media projects opinion polls during polling ... they also tally the results and project their results. World over opinion polls are used to predict elections outcomes. The media tally of presidential elections results to enhance transparency. In the December 2007 presidential election there was an argument of spontaneous votes from Kiambaa, Tharaka-Nithi and other parts of the country...the last minute and this changed the results in favour of Kibaki to the detriment of Odinga... The media like the other observers experience technical and capacity challenges ... and may not cover every polling station of a representative of all. Computer systems can be manipulated so electronic systems in the electoral process may not be immune to hacking ... most of the observers rely on the information from the media.

Out of this information, recurring themes across the rests of the interviews were world over horse-race coverage is a norm around presidential elections but they should not be relied on due to inconsistencies and media biases and partisanship which might condition public perception about certain candidates to the detriment of those not favoured. In addition the media was not very reliable in monitoring elections due to inability of the media to cover all polling stations and like any other observer; the media too, while it was used by the government in most cases to promote its preference, was limited in terms of access to the inner details of the electoral process.

In further interrogation, this was compared and it indeed compared with positions given by other respondents across the board. A key informant said, “...The opinion reports by Ipsos Kenya (formerly Synovate) and INFOTRAK were all supporting different organizations and whatever report and ... when they start they give a true reflection of the report but as they move on they are being used to change the narrative that the people who voted there...".

In light of the position given by the respondent mirroring submissions by most of them, opinion pollsters tend to attract the politicians to their business and after roping them in, use their research power to manipulate public opinion which shapes voter preferences by either exaggerating the opinions in favour of a particular candidate or against them whichever way keeps them in business. To this end, reliance on opinion polls by observers was seen to be misleading. This opinion is not bound to voters alone but affects the objective monitoring of both local and foreign observers. 
Another respondent charged:

...to a large extent local opinion affects what observers will have to say ... they don't have enough resources, they come for a very short time. Is local opinion objective? No, even the opinion polls are biased ... they are (locally) manipulated ... so the verdict reports of the monitors tend to be skewed-give the wrong information. How credible is the person giving opinion? For the statement is correct.

From this view, local observers most if not all of which consist of voters with political biases were equally affected by horse-race coverage. Local observers guided foreign observers on things to look out for as demonstrated by KEDOF briefing to IRI during the 2007 presidential elections; and ELOG to The Carter Center ahead of the 2013 and 2017 elections. This demonstrated that even foreign observers were influenced by public perception, not completely by their empirical findings.

This was supported by a respondent who had participated in the AUEOM:

...both local and international media are always very biased in the processes ... there are media houses that take sides ... in Kenya we are pretending ... politics influences the media ... this affects the observation process...it will not be objective ... observers also rely on the media as a source of information ... but they are partisan ... in 2007, when we called both the international and local media to alert them of rigging, they gave us blackout ... they only appeared when the rigging process had succeeded to make us look like we were just alarmists fearing losing...

The international media images of Kenya's electoral process came to question as it emerged that they were perceived to be biased or negative. Yet, most of the respondents were of the view that the transparency and accountability of Kenya's presidential elections required objective media that would cover in details the electoral process and deter fraud. Local media on the other hand was ruled out to be biased and promoting biased public opinion and partisan and could not enhance electoral transparency.

From the position of Member of the Senate, one of the key informants charged that:

...more so the media houses should have full access and the rests of the observers like in the recent US Presidential elections, the media were actually projecting the results as they were ... so that we do not have people coming up with figures last minute and force it on people like in the August 2017, 2013, and 2007. That system must be as open as the US system.

At the same time a number of domestic observers also displayed partisanship such as AfriCOG siding with the best loser to file election petitions against the EMB and the declared winner on the March 2013, and August 2017 presidential election (Kanyinga, 2017). 


\subsection{Effects of Public Opinion Conditioned by Political Parties on Election Monitor's Verdict on August 2017 Presidential Election}

The study sought to explain whether both foreign and local election observers specifically The Carter Center, African Union, Commonwealth, COMESA for foreign observers (COMESA, 2017), and ELOG for citizen observers ended up conferring legitimacy on the August 2017 presidential election due to misguiding public statements of political parties and the elections management body and the general perception they instilled in the public. Responses from the respondents were analyzed and presented as shown in Table 3.

From Table 3, it was observed that majority $269(72.1 \%)$ of the respondents said that most of the foreign and certain of the local election observers were unable to uncover illegal and dishonest practices during Kenya's presidential elections

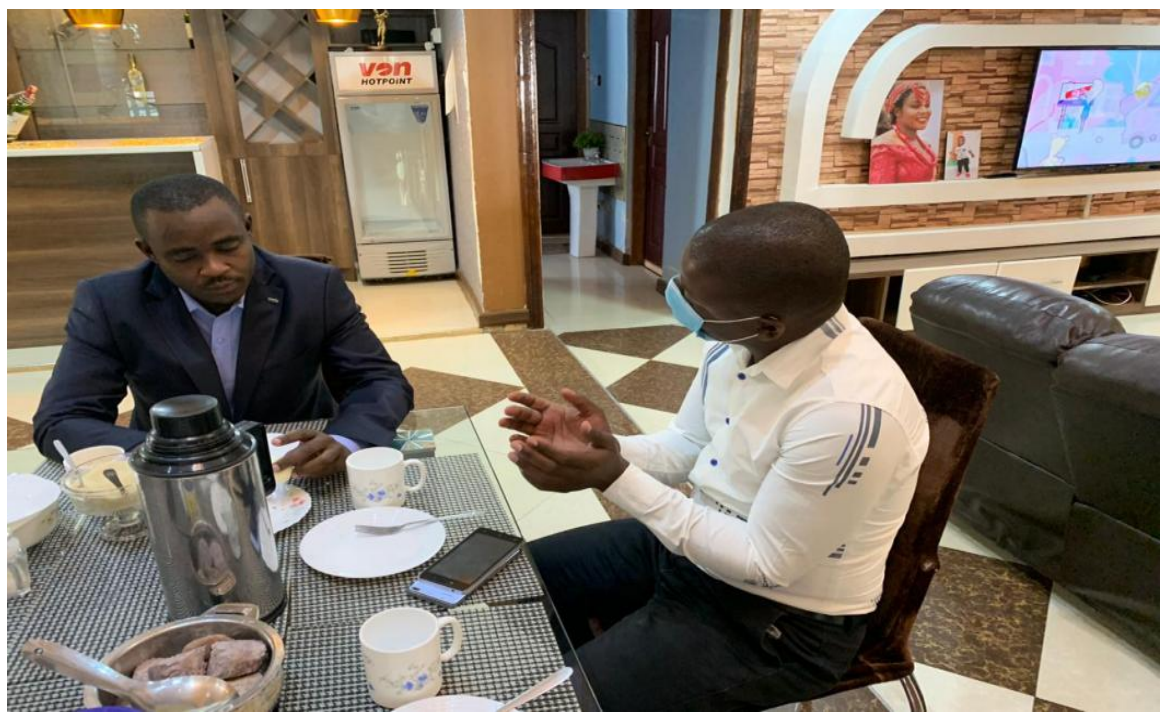

Plate 1. Researcher (without jacket) interviewing a Senator.

Table 3. Election monitors' conferment of legitimacy on August 2017 presidential election based on misguiding statements of political parties, the EMB, and general perception instilled in the public.

\begin{tabular}{ccccccc}
\hline & \multicolumn{2}{l}{$\begin{array}{l}\text { Do you believe both foreign and local election observers conferred } \\
\text { legitimacy on August 2017 presidential election due to misguiding } \\
\text { statements of political parties, the EMB, and general perception instilled in } \\
\text { the publics? }\end{array}$} & \multicolumn{2}{c}{ Yes } & No & \multicolumn{2}{c}{ Total } \\
\hline Twice & 66 & $72.5 \%$ & 25 & $27.5 \%$ & 91 & $100.0 \%$ \\
Thrice & 74 & $65.5 \%$ & 39 & $34.5 \%$ & 113 & $100.0 \%$ \\
four times & 73 & $73.7 \%$ & 26 & $26.3 \%$ & 99 & $100.0 \%$ \\
5 -7 times & 53 & $77.9 \%$ & 15 & $22.1 \%$ & 68 & $100.0 \%$ \\
Total & 277 & $72.1 \%$ & 107 & $27.9 \%$ & 384 & $100.0 \%$ \\
\hline
\end{tabular}


and only ended up conferring legitimacy on illegitimate presidential elections due to misguiding public statements of political parties and the elections management body and the general feeling they instilled in the public while 175 (27.9\%) of the respondents had a contrary opinion about the same.

The Cater Center unfortunately accused itself when having admitted it was difficult to verify the results announced by the EMB and instead resorted to data by a local observation team ELOG, which the study did not establish authenticity of its data, nor did the study confirm whether The Cater Center was able to verify; made its conclusions about the election from such a chaotic convenient scenario.

The Carter Center noted:

While the lack of IEBC polling-station data hindered the parties' ability to verify results, it is important to note that a Kenyan citizen election observation organization (Election Observation Group, or ELOG) conducted a parallel vote tabulation that provided an independent verification of the official results. ELOG's tabulation was based on results data gathered from a representative random sample collected by about 1700 observers deployed around the country. The parallel vote tabulation's estimated results, released on Aug. 11, were consistent with the IEBC's official results. (The Carter Center, 2018)

While noting the tallying by ELOG as important, what was important was for it to access IEBC and get the results and compare with its finding on the ground. In any case, out of the mixed opinion by all the three categories of respondents the weightier side of the responses on this question was generally. Interviewed respondents charged almost homogenously thus:

None of the 2007, 2013, and 2017 presidential elections was free and fair and the results were not credible. The reports by certain election monitoring entities that the elections were free and fair and that their results were credible were not true. It is a fact that reports from most of the local elections observer missions such as KNCHR and AfriCOG which discredited the processes and the results were more authentic contrary to the reports of most of the international election monitoring entities such as The Carter Center.

From the interview, The Carter Center basically along other foreign MTD EOMs to a great extent relied on local initiatives to draw their conclusions on the elections. Another respondent observed that most of the election observers did not actually go to the ground:

Although at times after elections especially 2007, 2013 and August 2017 they have been referenced in court, they do not conduct election monitoring but instead observation in literal sense ... which simply looks at the cosmetic aspects and they are laden with international interest and personal 
interests therefore may not be reliable and have proven using the 2017

(August) case unreliable.

In the view of the respondent and four others who held similar belief, the MTD EOMs therefore, instead did not do a good job despite the fact that they are supposed to do democratic critical assessment of the process and judge the electoral process as it was and give a concurrent judgment of its outcome. However, a good number of multi-track diplomacy (MTD) election observer missions (EOM) including The Carter Center, European Union (EU), and local ones such as Election Observation Group (ELOG), AfriCOG (Africa Center for Open Governance (AfriCOG), Kenya Election Domestic Observation Forum (KEDOF), did go to the ground and also did tally results despite the challenges they experienced.

\section{The Effects of Horserace Coverage}

The media takes the centre stage as the source of information to the voters especially for the presidential elections around the world and Kenya is not an exception. For a long time, the media was not largely accused negatively on the horse-race coverage in Kenya.

\subsection{Election Monitors' Reliance on Opinion Polls Projected by Media to Judge Elections}

Majority of Kenyan voters believed that election observers for the August 2017 presidential election were influenced by pre-election public opinion. This is elaborated in Table 4.

Findings from Table 4 shows that majority 281 (73.2\%) of the respondents said that the criticized report of foreign election observers led by The Carter Center on the August 2017 presidential election was influenced by varying

Table 4. Influence of pre-election public opinion the foreign monitors' reports.

\begin{tabular}{|c|c|c|c|c|c|c|c|}
\hline & \multirow[b]{3}{*}{ Male } & \multicolumn{6}{|c|}{$\begin{array}{l}\text { Do you believe the reports of election observers on the } \\
\text { August } 2017 \text { presidential election were influenced by } \\
\text { pre-election public opinion? }\end{array}$} \\
\hline & & \multicolumn{2}{|c|}{ Yes } & \multicolumn{2}{|c|}{ No } & \multicolumn{2}{|c|}{ Total } \\
\hline & & 144 & $74.2 \%$ & 50 & $25.8 \%$ & 194 & $100.0 \%$ \\
\hline \multirow[t]{4}{*}{ Gender } & Female & 136 & $72.0 \%$ & 53 & $28.0 \%$ & 189 & $100.0 \%$ \\
\hline & Total & 281 & $73.2 \%$ & 103 & $26.8 \%$ & 384 & $100.0 \%$ \\
\hline & Once & 11 & $84.6 \%$ & 2 & $15.4 \%$ & 13 & $100.0 \%$ \\
\hline & Twice & 67 & $73.6 \%$ & 24 & $26.4 \%$ & 91 & $100.0 \%$ \\
\hline $\begin{array}{c}\text { Number of } \\
\text { Times Voted for }\end{array}$ & Thrice & 72 & $63.7 \%$ & 41 & $36.3 \%$ & 113 & $100.0 \%$ \\
\hline \multirow{3}{*}{$\begin{array}{c}\text { President of } \\
\text { Kenya }\end{array}$} & four times & 72 & $72.7 \%$ & 27 & $27.3 \%$ & 99 & $100.0 \%$ \\
\hline & $5-7$ times & 59 & $86.8 \%$ & 9 & $13.2 \%$ & 68 & $100.0 \%$ \\
\hline & Total & 281 & $73.2 \%$ & 103 & $26.8 \%$ & 384 & $100.0 \%$ \\
\hline
\end{tabular}


pre-election public opinion which did not reflect the will of the majority at election while 103 (26.8\%) of the respondents disagreed.

It was observed that $144(74.2 \%)$ of the male and 136 (72\%) female respondents agreed to this while $53(25.8 \%)$ and $50(28 \%)$ of the male and female respondents respectively disagreed. From Table 4, majority of the voters, actually $86.8 \%$ of them who had voted more than five times were in agreement with this question while 41 (36.3\%) of the respondents who had voted thrice did not agree.

The media, the study found, was partisan and was influenced by political and businessmen anyway which own them, and the national broadcasting media the Kenya Broadcasting Corporation (KBC) controlled by the state such that the media gave airtime and blackout to political candidates depending on their relationships and this skewed behaviours manipulated the perception of the public or confused them in an environment where politics is ethnicized and subjective. In the 2007 elections, the state used the state-controlled KBC to its advantage just as KANU had done when it was in power. The EU EOM observed that:

While there were high levels of media coverage of the campaign, a number of media outlets monitored by the EU EOM failed to provide equitable coverage for candidates and parties. Most significantly, the Kenya Broadcasting Corporation (KBC) failed to fulfil(l) even its most basic legal obligations as a public service broadcaster, demonstrating a high degree of bias in favour of the Party of National Unity (PNU) coalition. While freedom of speech in the media was generally respected during the campaign period, immediately following the announcement of the final results of the presidential election on 30 December 2007 a Directive from the Internal Security Minister ordered broadcasters to suspend all live broadcasts, seriously infringing the right of the media to report freely and without fear of undue State interference. (European Union Election Observer Mission Kenya 2017, 2018: p. 2)

Of the 2007 elections, it was noted from the above excerpt that the media was blatantly biased. The national media-KBC failed to serve the opposition. However, that the reports came from another observer demonstrated a good level of objectivity on the monitors with respect to this particular election. The observer missions particularly the foreign ones were able to note the opinion poll biases and refrained leading to objective judgment of the process.

International media and painted negative media images about the Kenyan presidential elections at worst, propagated fake news trying to paint the environment as bleak as beyond the reality on the ground. This admittedly, the Commonwealth observed influenced both domestic factors including voters and as well, external stakeholders in the elections. The Commonwealth EOM in its report on the August 2017 elections wrote:

The main media concern in terms of the election was the proliferation of "fake news" and inflammatory online statements. It was alleged that both the ruling party and the opposition coalition had 'attack bloggers' and both 
the $\mathrm{BBC}$ and $\mathrm{CNN}$ had to react fast when stories started to circulate in an approximation of their branding and style. It is significant too that Facebook issued a press release (from South Africa) on ways to spot and identify 'fake news' in the Kenya election. Twitter was also used extensively for propaganda by the political groups as well as members of the public during the heated campaign. A study for GeoPoll during this period found that trust levels amongst Kenyans for social media as a source of election news was lower than that for mainstream media. However, despite this, a significant proportion of Kenyans cited social media as their main source of election news. (Commonwealth Secretariat, 2017: p. 3)

But of the 2017 elections, the findings indicated that the impact of public opinion in influence on voter preferences reduced. The fact that this was noted by foreign election observers meant that they too were weary of fake news and smear campaigns. They were objective enough to conduct their observation effectively.

According to most of the key informant respondents across the political divide and along the other factors of purposive selection, the media is fundamental to monitoring of Kenya's presidential election except that they had lower capacity to do objective monitoring of the elections and as well, local ones are laden with negative ethnicity and 'business mindedness' in which case they promote the political agenda of whomever pays them; and would also just opt to support a certain candidate; and for international ones, they may always want to show the world that Kenya is still a struggling democracy and therefore also depict it bleak. A respondent noted:

The media is equally biased and local ones are highly tribal. KBC (the national broadcasting corporation) usually tends to promote the political agenda of the incumbent as in December 2007 presidential election; the 'government preferred' candidate, and so was the case in the August 2017 presidential election. Their (observers') reports are very scanty and less informed as well... The reports are influenced by public opinion which has in turn been influenced by partisan media.

According to majority of the interviewees, the private ones are also by and large owned by the elites who also anyway control the circulation of elites in the power cycles and therefore have never been objective and cannot largely be relied on for objective election observation towards a conclusion as to the credibility of Kenya's presidential elections.

The campaigns were defined by political parties spending heavily in the media campaigns and use of the media to campaign (IRI, 2008; European Union Election Observer Mission Kenya 2017, 2008; The Carter Center, 2008). IRI in its report, and not different in the letter and spirit from those of the many other observers, in reference to the 2007 elections, submitted that dominant party more so the one for the government or its preferred candidate abused the state-owned or controlled media to campaign against and to the disadvantage of 
the opponent and in an attempt to condition public opinion to favour its intended rigging plans and outcome. IRI noted,

Aside from the specific problems relating to the ECK's operations in the counting and tallying of results, the use of state resources for campaigns is most troubling, and as a form of corruption, must be addressed through the criminal courts. The misuse of media resources is an especially pernicious but difficult to address problem. Bias in the state-owned broadcaster $\mathrm{KBC}$, the use of public resources to buy ads in the name of government agencies and entities for partisan purposes, and rewarding or punishing private-owned media in accordance with how they cover the government and opposition must be addressed. Transparency and accountability for all media expenditures by the government is necessary. (IRI, 2008: p. 36)

The study conducted in Kenya on the influence of public opinion on observers' critical assessment of Kenya's presidential election outcomes found thatt there was an attempt by a major party to create a negative perspective against the competing or plainly, the opposing party so as to depict a picture that the other party feared losing to the party which had designed public opinion to reflect the notion. In the nearly all of the interviews, it particularly emphasised, according to one respondent that:

Opinion polls can be misleading therefore observers as well as citizens should not necessarily rely on it. "...No we should not (rely on opinion polls to predict the outcome of elections unless it is based on) objective criteria... A lot of opinion polls have been used to manipulate electoral results.

The presidential elections were conducted according to laid down procedures against which they ought to be observed for objective judgment of the process, anyway, not the outcome. Reliance of MTD EOMs on public opinion might have watered down their judgments of the August 2017 presidential election such that they relied on manipulated opinion polls as convenient techniques.

Perspectives from FGD participants were as follows: from expert FGD which was the second FGD conducted, remarks in unanimity were that, "...opinion polls are business... The system predetermines outcomes of elections and shapes public perception to reflect the same..."; “...opinion polls do not help the EOMwho pays them?"; "...that thing is a business".

A senior national woman leader charged that opinion polls lie and if observers relied on their statements and reports, they cannot be reliable for conclusion as to whether the elections were free and fair and their outcome credible:

Opinion polls lie ... they are not objective ... the opinion pollsters are partisan ... subjective ... in 2007 they made it look like Kibaki was winning against Odinga while although doctored to reflect the opinion poll outcomes, Odinga won but was denied the win. Their (observers') reports are very scanty and less informed as well ... The reports are influenced by public opinion which has in turn been influenced by partisan media... At best 
observers just do public relations with their reports... They tend to reserve the truth to themselves if at all they come across it, largely by accident because they are not always keen on digging deeper into the truth.

In their various reports, election observers especially the international ones accused themselves of relying on local political parties to understand the situation in the country to inform their observation, and the researcher believed this might have heavily borne on their reports. IRI for example wrote,

IRI delegates and staff involved in the observer mission held meetings with experts on Kenyan politics, representatives of Kenyan political parties and leaders from civil society and international organizations that operate in Kenya to gain a better understanding of the political environment leading up to the elections... Delegates and staff were first briefed on the overall political situation. Kenya Domestic Observer Forum (KEDOF) briefed IRI's delegation on its domestic observation efforts, how it viewed the campaign period and specific things for which election observers should be on the lookout... In addition, ODM representatives gave a brief presentation to the delegation. The representatives raised concerns over alleged ploys by PNU to rig the elections. (IRI, 2008)

IRI, from the excerpt is admitting being directed by KEDOF on what to observe, and so this might have been done to them by the political parties as well as the EMB. This was observed to have happened in all the presidential elections.

\subsection{Influence of Propaganda and Fake News on Election Monitors' Reports}

Public perception may be influenced by propaganda: intentional and step by step strategically crafted attempts to manipulate the perception, opinion, and values

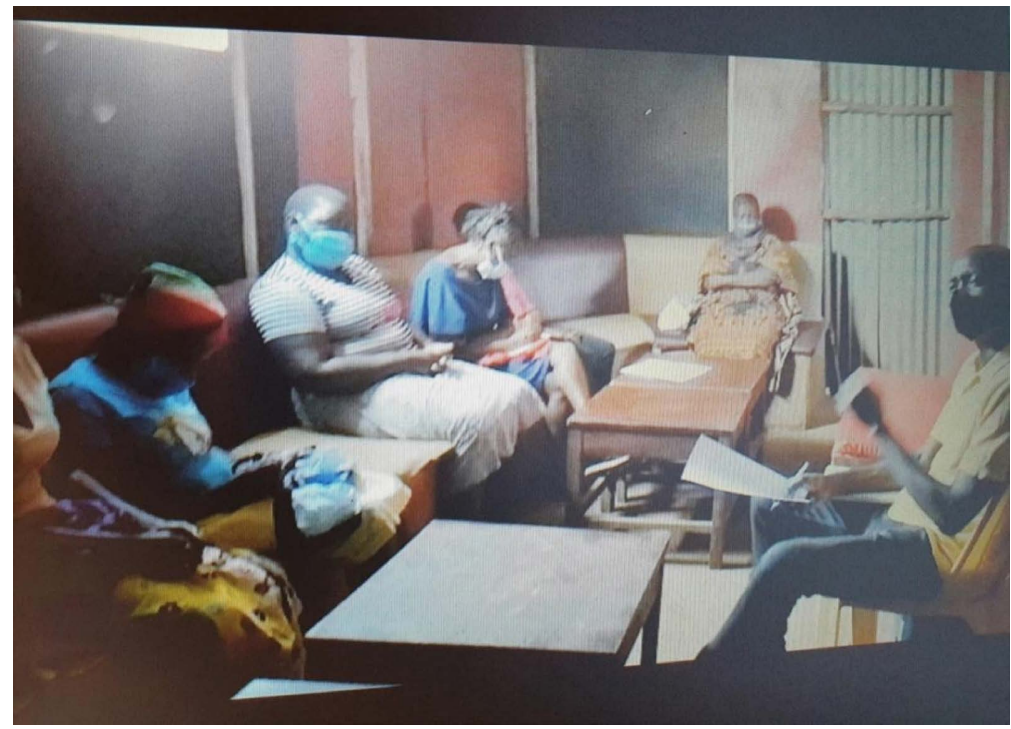

Plate 2. Researcher, Front right (in black mask and yellow shirt) facilitating FGD with a natural group, in Mathare, Nairobi. 
of the public to influence the thinking and understanding of the target public in the interest of the propagandist (Nkwede \& Itumo, 2016: p. 4; Nwogbaga, 2016).

The propagandist may employ testimonials whereby they appeal to the person and authority highly regarded or eminent personalities or respected and respectable regimes and institutions to authenticate and endorse or malign or criticize an idea (Nkwede \& Itumo, 2016: p. 4).

The study established the reports by international election observations missions to Kenya's presidential elections between 2007 and 2017 were based on propaganda by a party to retract the horizons of realities. Elaborate statistical information from which the finding was revealed is in Table 5.

From Table 5, majority 214 (55.7\%) of the respondents said that the reports by international election observations missions to Kenya's presidential elections between 2007 and 2017 were based on propaganda by a party to retract the horizons of realities while 179 (44.3\%) of the respondents were in disagreement. Based on gender, 114 (58.8\%) of the male and $100(52.9 \%)$ of the female respondents agreed to this question while $80(41.2 \%)$ and $89(47.1 \%)$ respectively of the male and female respondents disagreed.

In Figure 1, the blue segment depicts the majority 214 (55.7\%) of the 384 (total number of respondents who participated in the survey) who believed the observers particularly foreign ones and ELOG, a domestic one, conferred legitimacy of illegitimate outcome of the August 2017 results, while; represented by the red segment $170(44.3 \%)$ of the total number of respondents who held their view on the same argument to the contrary.

Propaganda was reported to be a key factor even from the reports of international

Table 5. MTD EOMs conferment of legitimacy on illegitimate presidential elections outcome, 2007-2017 due to propaganda.

\begin{tabular}{cccccccc}
\hline & & \multicolumn{6}{c}{$\begin{array}{c}\text { Do you believe the reports MTD EOMs were based on } \\
\text { propaganda by a party to retract the horizons of realities? }\end{array}$} \\
\cline { 3 - 7 } & & \multicolumn{2}{c}{ Yes } & & No & Total \\
\hline Gender & 114 & $58.8 \%$ & 80 & $41.2 \%$ & 194 & $100.0 \%$ \\
& Female & 100 & $52.9 \%$ & 89 & $47.1 \%$ & 189 & $100.0 \%$ \\
& Total & 214 & $55.7 \%$ & 170 & $44.3 \%$ & 384 & $100.0 \%$ \\
\hline
\end{tabular}

\section{Do you believe that election monitors conferred legitimacy on illegitimate August 2017 presidential elections outcome due to propaganda}

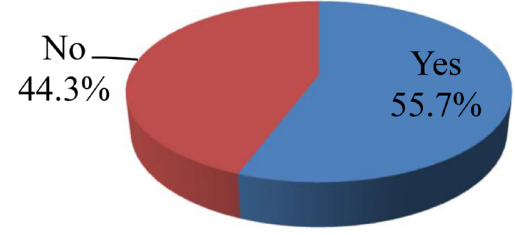

Figure 1. Views of respondents that EOMs conferred legitimacy on illegitimate presidential elections outcome, 2007-2017 due to propaganda. 
election observer missions. The Commonwealth EOM reported that, while, freedom of speech is guaranteed in the Constitution the Group was told that commercial pressures, and the threat or withdrawal of government advertising creates a risk adverse atmosphere that affects journalistic independence. In its greater concern, the Commonwealth Secretariat reporting on Kenya's presidential election observation wrote:

The main media concern in terms of the election was the proliferation of 'fake news' and inflammatory online statements. It was alleged that both the ruling party and the opposition coalition had 'attack bloggers' and both the $\mathrm{BBC}$ and $\mathrm{CNN}$ had to react fast when stories started to circulate in an approximation of their branding and style. It is significant too that Facebook issued a press release (from South Africa) on ways to spot and identify 'fake news' in the Kenya election. Twitter was also used extensively for propaganda by the political groups as well as members of the public during the heated campaign. (Commonwealth Secretariat, 2018)

This showed objective analysis of Kenya's electoral environment by MTD EOMs especially foreign ones and to that extent they remained objective and appeared to be devoid of propaganda influence. The International Republican Institute went further to discuss in details the nature and modes in which the propaganda was used to influence the public, and the researcher was persuaded to believe, even the observers. IRI going deeper than European Union Election Observer Mission Kenya 2017 (2008) noted that political candidates resorted to ethnic and tribal epithets or hate speech when campaigning. It further observed that by utilizing inflammatory and discriminatory remarks in campaign rallies and in vernacular media, candidates inflamed ethnic tensions that contributed to post-election violence. It noted with concern that:

...Kenyan elections are made more vulnerable to fraud by the fact that parties and candidates tend to have strong ethnic, tribal and regional associations, such that while an election may be closely contested nationally, in many areas there is some level of popular tolerance for rigging or intimidation on the basis of a perceived commonality of interest by a one-sided majority. (IRI, 2008: p. 38)

This observation by IRI was contrary to the belief of most of the respondents who believed foreign observers or all observers were influenced by propaganda thus unable to effectively monitor and report objectively on the electoral process. By and large, this observation was very detailed and reflected the findings in the Kriegler/IREC Report (2008) as well as the Waki/IREC Report (2008) that there were instances and evidences of rigging in the strongholds of both Odinga and Kibaki leading to the disputed 2007 presidential elections.

However, this seemed to have change following the inconsistency of most MTD EOMs reports with the verdict of the Supreme Court annulment of the August 2017 presidential election. Propaganda, it was also believed by a number 
of respondents, became convenient also due to lack of transparency in the conduct of the elections by the EMB. However, some of the key informant interview respondents had a contrary opinion. According to one of the respondents who were a senior officer in the Directorate of Africa and AU of the Ministry of Foreign Affairs and International Trade the observers might not have relied on propaganda but were actually limited by the EMB on what to observe and what not to observe, limiting their judgment. The officer averred that:

...with the 2017 election it was a bit peculiar for instance one complaint that I had mentioned a lot by election observers for instance is that they were not given access to the back end of the system. You know that was tallying the elections ... if you are not given access you will only report on what you see. So it may have been limited in that sense but whether these election observers just took the propaganda of a specific party to distort the reality, I do not believe so.

Evidently, MTD EOMs were denied access by the EMB but they did not sideline a particular party except that they had no option but to judge the elections based on the results announced by the EMB. In its observation of the December 7, 2020 Ghanaian presidential and parliamentary elections, AU EOM in view of the fact that the media had been used or internationally and on its own volition as interpreted by the researcher, disseminated misinformation, disinformation, and inflammatory messages by or in favour of the incumbent or even without his approval or direct involvement noted, but against the opposition.

In the reports, with concern, the EOM recommended that the respective political divides, "...to demonstrate professionalism and impartiality by refraining from disseminating misinformation, disinformation and inflammatory messages that would further polarize society and incite violence (AU, 2020: p. 10). Generally, as a tradition reports of election observers especially the foreign MTD actors had a section on the media. With concerns, they stressed on the media more than other aspects. To that extent, MTD EOMs demonstrated possibility of media and propaganda influence on the MTD EOMs but this did not completely override their objectivity.

\subsection{Influence of Citizens on Multi-Track Diplomacy Election Observers}

The reports of most of the MTD EOMs on the August 2017 presidential election were considered to have been based on the cosmetic aspects of the elections. Therefore, they were suspected to be less-comprehensive. Majorly questioned were the reports by the AU EOM, COMESA EOM, The Carter Center EOM, and The Commonwealth Secretariat (Nginya, 2018; IGAD, 2017; AU, 2018; COMESA, 2017). These entities were argued to not to have been in touch with the realities with regards to MTD actors reports on Kenya's presidential elections. Outstandingly castigated by Odinga and his sympathizers were the AU EOM, COMESA EOM, the Carter Center EOM, and The Commonwealth Secretariat. The leaders 
of the delegations of the respective EOMs such as Mbeki, Kerry, and Mahama were argued to have favoured Kenyatta.

This speculation influenced the researcher to investigate the perception of the respondents in quest for new knowledge. The study sought to establish whether the International election observer missions to Kenya's December 2007, March 2013, August 2017, and October 2017 presidential election provided less comprehensive and less-close-to-reality conclusions for the August 2017 presidential election due to local opinion. Responses for this question were analyzed and presented as shown in Table 6.

Findings from Table 6 indicated that majority 269 (70.1\%) of the respondents said that the MTD EOMs for Kenya's December 2007, March 2013, August 2017, and October 2017 presidential election were not competent. It was noted that most of the respondents retorted that the election observers provided less comprehensive conclusions for the August 2017 presidential election. This was because they did not have long term and analytical relationship with local civil society initiative.

However, the minority (29.9\%) of the respondents held contrary opinion. Based on gender, $138(71.1 \%)$ of the male and $131(69.3 \%)$ of the female respondents believed such argument. On the contrary, 28 (28.9\%) and 4 (30.7\%) of the male and female respondents respectively disagreed. Largely the respondents did

Table 6. Effects of local opinion on quality of foreign EOMs monitoring.

\begin{tabular}{|c|c|c|c|c|c|c|c|}
\hline & \multirow[b]{3}{*}{ Male } & \multicolumn{6}{|c|}{$\begin{array}{l}\text { Do you believe foreign EOMs provide less comprehensive and } \\
\text { less-close-to-reality conclusions for the August } 2017 \text { presidential } \\
\text { election because they did not investigate local opinion? }\end{array}$} \\
\hline & & \multicolumn{2}{|c|}{ Yes } & \multicolumn{2}{|c|}{ No } & \multicolumn{2}{|c|}{ Total } \\
\hline & & 138 & $71.1 \%$ & 56 & $28.9 \%$ & 194 & $100.0 \%$ \\
\hline \multirow[t]{4}{*}{ Gender } & Female & 131 & $69.3 \%$ & 58 & $30.7 \%$ & 189 & $100.0 \%$ \\
\hline & Total & 269 & $70.1 \%$ & 115 & $29.9 \%$ & 384 & $100.0 \%$ \\
\hline & Once & 9 & $69.2 \%$ & 4 & $30.8 \%$ & 13 & $100.0 \%$ \\
\hline & Twice & 65 & $71.4 \%$ & 26 & $28.6 \%$ & 91 & $100.0 \%$ \\
\hline \multirow{7}{*}{$\begin{array}{l}\text { Number of Times } \\
\text { Voted for } \\
\text { President of Kenya }\end{array}$} & Thrice & 74 & $65.5 \%$ & 39 & $34.5 \%$ & 113 & $100.0 \%$ \\
\hline & four times & 71 & $71.7 \%$ & 28 & $28.3 \%$ & 99 & $100.0 \%$ \\
\hline & 5 - 7 times & 50 & $73.5 \%$ & 18 & $26.5 \%$ & 68 & $100.0 \%$ \\
\hline & Total & 269 & $70.1 \%$ & 115 & $29.9 \%$ & 384 & $100.0 \%$ \\
\hline & None & 7 & $58.3 \%$ & 5 & $41.7 \%$ & 12 & $100.0 \%$ \\
\hline & Primary & 53 & $75.7 \%$ & 17 & $24.3 \%$ & 70 & $100.0 \%$ \\
\hline & Secondary & 88 & $72.7 \%$ & 33 & $27.3 \%$ & 121 & $100.0 \%$ \\
\hline \multirow{4}{*}{$\begin{array}{c}\text { Level of Formal } \\
\text { Education }\end{array}$} & VTC & 48 & $76.2 \%$ & 15 & $23.8 \%$ & 63 & $100.0 \%$ \\
\hline & College & 37 & $61.7 \%$ & 23 & $38.3 \%$ & 60 & $100.0 \%$ \\
\hline & University & 36 & $62.1 \%$ & 22 & $37.9 \%$ & 58 & $100.0 \%$ \\
\hline & Total & 269 & $70.1 \%$ & 115 & $29.9 \%$ & 384 & $100.0 \%$ \\
\hline
\end{tabular}


not trust that the MTD actors that observed Kenya's presidential elections did a comprehensive work. Therefore, they were less comprehensive.

Further analysis using the other demographic factors confirmed such. Basing analyses on formal level of education of the respondents, majority $48(76.2 \%)$ of the respondents who had VTC training agreed to this question while 5 (41.7\%) of the respondents who had no formal education disagreed. Figure 5.5 simplifies this information in a visual and easy to understand form. The blue segment expresses the belief that foreign election monitors provided less comprehensive conclusions on the elections due to failure to investigate local opinion.

From Figure 2, the blue segment of the pie chart indicates the views of majority $269(70.1 \%)$ of the 384 total number of respondents, who believed that failure by foreign election observers to exhaust exploring relations with local observers explained the less-comprehensive reports they gave about the August 4, 2017 presidential elections in Kenya. The red segment is a visual representation of the distribution of the views of the respondents, 115 (29.9\%) of the total number who did not hold such a belief. While $70 \%$ of survey respondents observed those foreign election observers' reports were less comprehensive and less close to reality because they did not rely on local opinion, reports from certain but also very key and renowned election observer missions admitted partnership even with local observers. The Carter Center for example drew its conclusion on the August 2017 presidential election from the processes and results tallied by ELOG.

The misnomer is that these observers also noted the challenges they mutually faced with the local initiatives including inability to access the technology the IEBC was using to tally the results, a problem even the opposition party had: the server. In addition, noted the EU EOM on the August 2017 elections, local actors around election observation and human rights issues around the election generally, were they frustrated by the state?

Key civil society organisations and networks were subject to intimidating state actions just before each of the two deadlines for lodging presidential

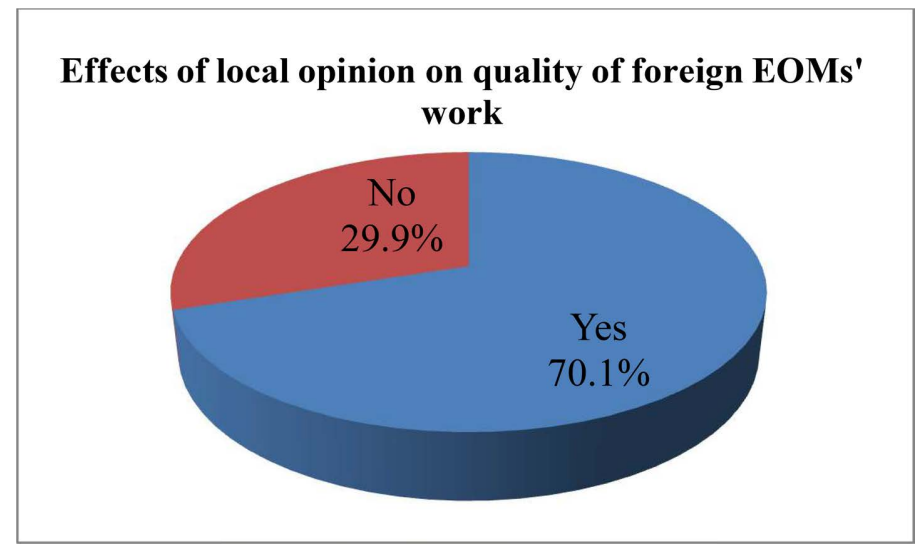

Figure 2. Pie chart on whether foreign election monitors provided less comprehensive conclusions on due to failure to investigate local opinion. 
petitions (in August and November). The media provided increasing scrutiny of the process, but could not always report freely and attempts were made to restrict live coverage of disturbances. (European Union, 2018)

From the information obtained from the analyses, it is observed that the responses indicate to a higher expectation of voters of the work and reports of election observers. However, much as elections are a process, not a one-day event, wherefore comprehensive observation must carefully evaluate and assess the entire pre-election period (OSCE/ODIHR, 2004), the election period, and post-election developments, as well as what happens on election-day; election observation does not have to be comprehensive; it can also be designed to focus on a specific region, or on a particular aspect of an election. (OSCE/ODIHR, 2004)

The local opinion was also by and large influenced and shaped by the media, the platform for political campaigns and political and electoral education among others, were themselves termed biased and partisan, full of fake news and propaganda. Interestingly again, the media was also controlled by the stake either to its advantage or by intimidation to frustrate the opposition and to façade the ill-doings of the government. The Commonwealth noted:

Key civil society organisations and networks were subject to intimidating state actions just before each of the two deadlines for lodging presidential petitions (in August and November). The media provided increasing scrutiny of the process, but could not always report freely and attempts were made to restrict live coverage of disturbances. (The Commonwealth, 2018: p. 2)

However, a number of civil society organizations such as ELOG on which a number of foreign EOMs such as IRI and KEDOF depended for detailed reporting, monitored Kenya's presidential elections.

\section{Conclusion}

This study noted that the Kenyan presidential election environment is characterised by public opinion as a factor. This played between and among: the media both as a facilitator of public and political communication and information, interested political sponsor; voters; the rest of the multi-track diplomacy MTD actors monitoring elections both local and foreign; the political parties and political candidates; and the election managements body (EMB), but not limited to these mentioned. Election monitors were influenced by media both local and international which were partisan and broadcasted fake news. The observers were also affected by tribal politics. Generally, election monitors were influenced by public opinion more so on opinion polls and political campaign media portrayal of the electioneering situation in the country. Their observation was affected by information from public opinion designed by the dominant political parties. Their credibility in terms of critical assessment of Kenya's presidential elections 
was negatively affected.

\section{Acknowledgements}

We thank the Almighty God for good health, wisdom and knowledge that enabled us to conduct this study and write this article. We thank the editorial team for accepting this work.

\section{Conflicts of Interest}

The authors declare no conflicts of interest regarding the publication of this paper.

\section{References}

African Union (2020). African Union Election Observer Mission to the 7 December 2020 Presidential and Parliamentary Elections in Ghana (Preliminary Report).

AU (African Union) (2018). African Union Election Observer Mission to the 7 August 2017 Presidential and Parliamentary Elections in Kenya (Final Report). https://au.int/en/documents/20190514/report-african-union-election

Braemoeller, B. F., \& Satori, A. E. (2002). Empirical-Quantitative Approaches to the Study of International Relations. In D. F. Sprinz, \& Y. Wolinsky (Eds.), Cases, Numbers, Models: International Relations Research Method (Vol. 41, No. 2, pp. 139-163).

Brown, C. (2013). The Poverty of Grand Theory. European Journal of International Relations, 19, 483-497. https://doi.org/10.1177/1354066113494321

Burchill, S., \& Linklater, A. (2009) Introduction. In S. Burchill, \& A. Linklater (Eds.), Theories of International Relations (5th ed.). Palgrave Macmillan.

Burchill, S., Linklater, A., Devetak, R., Donnelly, J., Nardin, T., Pa-terson, M., Reus-Smit, C., \& True, J. (2013). Theories of International Relations (5th ed.). Palgrave Macmillan.

Bush, S. S., \& Prather, L. (2018). Who's There? Election Observer Identity and the Local Credibility of Elections. International Organization, 72, 659-692.

https://doi.org/10.1017/S0020818318000140

COMESA (2017). COMESA Lauds Kenya for Conducting Peaceful Elections.

Commonwealth Secretariat (2018). Kenya General Elections 7 August 2017: Report of the Commonwealth Observer Group. The Commonwealth.

Cox, G. W., \& Weingast, B. R. (2017). Executive Constraint, Political Stability, and Economic Growth. Comparative Political Studies, 51, 279-303. https://doi.org/10.1177/0010414017710254

Elklit, J., \& Reynolds, A. (2010). Judging Elections and Election Management Quality by Process. Journal of Representative Democracy, 41, 189-207.

European Union Election Observer Mission Kenya 2017 (2008). 27 December 2007 Final Report on the General Elections. European Commission. http://www.eods.eu/library/final_report_kenya_2007.pdf

European Union Election Observer Mission Kenya 2017 (2018). Republic of Kenya 2017 General Elections Final Report (10 January 2018).

http://www.eods.eu/library/eu_eom_kenya_2017_preliminary_statement_31_october_f inal.pdf

Feyerabend, P. (1975). Against Method: Outline of an Anarchistic Theory of Knowledge. New Left Books. 
Gibson, C., \& Zimmerman, B. (2015). Democratization in Africa. In S. Maisel (Ed.), $O_{X^{-}}$ ford Bibliographies in Political Science. Oxford University Press.

Global Network of Domestic Election Monitors (GNDEM) (2018). Declaration of Global Principles for Non-Partisan Election Observation and Monitoring by Citizen Organizations (DOGP) and Code of Conduct for Non-Partisan Citizen Election Observers and Monitors. Commemorated April 3, 2012. United Nations.

IGAD (Inter-Governmental Authority on Development) (2017). Statement on the General Elections in Kenya from the IGAD Chair Person.

https://igad.int/press-release/1622-state-ment-onthe-general-elections-in-Kenya-fromthe-IGAD-chair-person

IRI International Republican Institute (2008). Election Observation Report: Kenya's 2007 Presidential, Parliamentary and Local Elections.

Kanyinga, K. (2017, January 15). Why Government and NGOs Aren't Friends, and What Not to Do about It. Sunday Nation. Nation Media Group.

Kelley, J. (2009). D-Minus Elections: The Politicsand Norms of International Election Observation. International Organization, 63, 765-787.

https://doi.org/10.1017/S0020818309990117

Kelley, J. (2010). Election Observers and Their Biases. Journal of Democracy, 21, 158-172. https://doi.org/10.1353/jod.0.0173

Kriegler/IREC Report (2008). Report of the Independent Review Commission on the General Elections Held in Kenya on 27 December 2007. IREC.

Lamont, C. (2015). Research Methods in International Relations. Sage.

Laugesen, H. (2017). Kenya's Elections-The Wicked Stepmother of Democracy? African Security Review. http://mc.manuscriptcentral.com/rasr

Linklater, B. (1996). The Achievements of Critical Theory. In: S. Smith, K. Booth, \& M. Zalewski (Eds.), International Theory: Positivism and Beyond (pp. 279-298). Cambridge University Press.

Lynge-Mangueira, H. (2012). Why "Professionalizing” International Election Observation Might Not Be Enough to Ensure Effective Election Observation. International Institute for Democracy and Electoral Assistance. International IDEA.

Mapendere, J. (2000). Track One and a Half Diplomacy and the Complementarity of Tracks. Culture of Peace Online Journal, 2, 66-81.

McDonald, J. W. (2003). Multi-Track Diplomacy. In G. Burgess, \& H. Burgess (Eds.), Beyond Intractability. Conflict Information Consortium, University of Colorado. http://www.beyondintractability.org/essay/Multi-track-diplomacy

Moore, A. (2018). Conspiracies, Conspiracy Theories and Democracy. Political Science Review, 16, 2-12. https://doi.org/10.1111/1478-9302.12102

Moy, P., \& Eike, M. (2012). Attitudinal and Behavioral Consequences of Published Opinion Polls. In J. Strömbäck, \& C. Holtz-Bacha (Eds.), Opinion Polls and the Media: Reflecting and Shaping Public Opinion (pp. 225-245). Palgrave Macmillan.

https://doi.org/10.1057/9780230374959_11

Natolooka, K. (2017). The Efficacy of Multi-Track Diplomacy in Resolving Intrastate and Internationalized Conflicts in Africa: The Case of the 2007/2008 Post-Election Violence in Kenya. Doctoral Dissertation, Rhodes University.

Ndulo, M., \& Hong, D. U. (2017). International Observers, and the Monitoring of National Elections. In Democracy and Electoral Politics in Zambia (pp. 313-333). Brill Publishers. 
Nginya, M. (2018). International Election Observers in Kenya's 2017 Elections: Impartial or Partisan? Journal of African Elections, 17, 49-71. https://doi.org/10.20940/JAE/2017/v16ila3

Nkwede, J. O., \& Itumo, A. (2016). Fundamentals of Political Science. Peace Concepts 2016. Ginika Graphics and Prints.

Norris, P., Frank, W. R., \& Comai, M. F. (2013, October). Assessing the Quality of Elections. Journal of Democracy, 24, 124-135.

Nwogbaga, D. M. E. (2016). Public Opinion and Propaganda in Governance. In J. O. Nkwede, \& A. Itumo (Eds.), Fundamentals of Political Science (pp. 1-9). Abakaliki.

OSCE/ODIHR (2004). Handbook for Monitoring Women's Participationin Elections. OSCE/ODIHR. https://www.osce.org/odihr/elections/13938

Owiso, M. O. (2017). Transitional Justice and the Institutionalisation of Democracy: Historical Legacies and the Truth Process in Kenya. Doctoral Dissertation, Aalborg University.

Saltman, R. G. (2006). Independent Verification: Essential Action to Assure Integrity in the Voting Process. National Institute of Standards and Technology.

Shah, S. (2015). Local versus International Standards of Elections Assessment: Kenya's 2013 General Elections. In F. Otieno (Ed.), New Constitution, Same Old Challenges: Reflections on Kenya's 2013 General Elections (pp. 36-46). Society for International Development (SID)/Uraia Trust.

Tapoko, G. C. (2017). Election Observation and the Question of State Sovereignty in Africa. Journal of African Elections, 16, 46-71.

The Carter Center (2018). Kenya: Final Report, 2017 Kenya Generaland Presidential Elections.

Udeuhele, G. I. (2011). Public Opinion and Propaganda. Abakaliki Press.

United Nations (2005). Secretary-General Endorses Principles for Election Observation, Calls on International Community to Make Full Use of Guidelines.

https://www.un.org/press/en/2005/sgsm10190.doc.htm

Waki, P., \& IREC (2008). Report of the Independent Review Commission on the General Elections Held in Kenya on 27th December, 2007. Kenya Law.

http://www.kenyalaw.org/kl/index.php/fileadmin/CommissionReports/fileadm

Wanyande, P. (1987). Democracy and the One-Party State: The African Experience. East African Publishers. https://carijournals.org

Whetten, D. A. (1989). What Constitutes a Theoretical Contribution? Academy of Management Review, 14, 490-495.

Williams, M. C. (2004). Why Ideas Matter in International Relations. Cambridge University Press. 